\title{
KOMUNITAS
}

\section{KAJIAN STRATEGI ADAPTASI BUDAYA PETANI GARAM}

\author{
Dhedy Pri Haryatno $\bowtie$
}

SMAN 1 Rembang, Jawa Tengah, Indonesia

\section{Info Artikel}

Sejarah Artikel:

Diterima Juni 2012

Disetujui Juli 2012

Dipublikasikan September 2012

Keywords:

Adaptation;

Cultural strategy;

Salt farmers.

\begin{abstract}
Abstrak
Bledug Kuwu merupakan fenomena semburan lumpur yang mengandung garam sehingga dimanfaatkan sebagai garam dapur. Profesi sebagai pembuat garam dapur yang dilakukan penduduk sekitar dalam sepuluh tahun terakhir ini telah mengalami penurunan cukup drastis yaitu dari seratus orang pada tahun 2000 menjadi hanya enam orang pada tahun 2010. Dalam penelitian ini penulis menggambarkan strategi adaptasi budaya petani garam. Dalam penelitian ini digunakan pendekatan kualitatif serta teknik observasi, wawancara, dan dokumentasi. Lokasi penelitian adalah di desa Kuwu, Grobogan. Hasil penelitian menunjukkan adanya permasalahan lingkungan yang dihadapi oleh petani garam yakni perubahan cuaca yang tidak menentu, kondisi lumpur yang selalu berubah, dan karakteristik air garam. Untuk menghadapi problem lingkungan, petani garam melakukan adaptasi kultural yaitu menghindari bahaya yang ada di lingkungan. Selain itu, petani juga memiliki keterbatasan dalam teknologi pembuatan garam. Juga ditemukan perubahan teknologi yang digunakan dalam pembuatan garam seperti klakah, blonjong, siwur, kepyur, payon, ember, dan kerik juga harus dilakukan. Ada juga upaya lain antara lain melalui perilaku penimbunan garam, membuat peralatan pembuat garam sendiri, dan mencari pekerjaan sambilan lain yang dapat menjadi alternatif pemenuhan ekonomi warga. Sementara itu dukungan secara moral dan material dari pemerintah juga sangat dinantikan.
\end{abstract}

\begin{abstract}
Bleduk Kuwu is a salt mudflow phenomena in Kuwu Grobogan that can processed into table salt. Profession as salt makers in the last ten years has decreased quite dramatically, from a hundred people in 2000 to just six people in 2010. The objective of this study is to explore the adaptation strategy of the salt peasant in Kuwu Grobogan. In this study, the author uses a qualitative approach to its base, with observation techniques, interviews, and documentation in its data collection. The research found that the challange of salt farmers are environmental problems, which include erratic weather changes, the ever-changing sludge conditions, and characteristics of salt water. To deal with environmental problems, salt farmers adapt culturally to avoid the dangers that exist in the environment. Changes in technology used in the manufacture of salt as klakah, blonjong, siwur, kepyur, payon, buckets, and kerik is also observed. There are also other strategies, which include salt buildup, making their own saltmaking equipment, and look for other jobs for economic fulfillment. Meanwhile, the moral and material support from the government is also highly needed.
\end{abstract}

(C) 2012 Universitas Negeri Semarang

\footnotetext{
Alamat korespondensi:

Jln. Gajah Mada No 5 Rembang, Jawa Tengah, Indonesia, 51123

ISSN 2086-5465

E-mail: dhedy_priharyatno@yahoo.co.id
} 


\section{PENDAHULUAN}

Awal kemunculan letupan lumpur yang berada di Desa Kuwu sudah ada sejak era kerajaan-kerajaan Jawa pada masa lalu, dan tidak ada catatan sejarah Bledug Kuwu di karya Empu Tantular ataupun Empu Prapanca. Menurut legenda terjadinya Bledug Kuwu yang merupakan salah satu cerita rakyat yang ada di Desa Kuwu, Bledug Kuwu terjadi karena ulah Joko Linglung pada masa kerajaan Medang Kamolan yang waktu itu diperintah oleh Raja Aji Saka setelah mengalahkan Prabu Dewata Cengkar.

Keluarnya air yang terasa asin tersebut, membuat masyarakat Desa Kuwu memanfaatkan untuk dibuat sebagai garam dapur. Profesi pembuat garam dapur sampai sekarang masih dapat dijumpai di sekitar kawasan Bledug Kuwu, namun kondisinya sudah berbeda dengan awal kemunculan air garam tersebut. Pada kurun waktu 10 tahun terakhir jumlah petani garam adalah 100 orang, namun sekarang hanya tinggal 6 yang masih mempertahankan usahanya.

Dengan terdapatnya 6 petani garam yang masih bertahan di Desa Kuwu, identitas lokal sebagai masyarakat petani masih dipegang kuat. Hal ini ditandai dengan rasa kebersamaan dan tolong-menolong antar sesama petani garam yang masih ditunjukkan dalam menjalankan setiap aktifitas. Dalam kehidupan petani garam di Desa Kuwu terkesan masih sederhana dan dapat dikatakan belum berkembang, karena pada dasarnya petani garam berorientasi pada pemenuhan kebutuhan sehari-hari. Dengan adanya Bledug Kuwu memberikan dampak kepada masyarakat Desa Kuwu baik secara sosial maupun ekonomi. Salah satu fungsi sosial ekonomi masyarakat pedesaan di Indonesia adalah melakukan berbagai macam kegiatan produksi dengan orientasi hasil produksinya untuk memenuhi kebutuhan pasar baik di tingkat desa maupun ditingkat lain yang lebih luas.

Penurunan jumlah petani garam di Desa Kuwu dapat menjadi pertanda bahwa semakin ditinggalkannya profesi petani garam di lingkungan masyarakat Desa Kuwu. Pendapatan yang tidak menentu disertai dengan kebutuhan hidup yang semakin meningkat, menuntut petani garam untuk beralih pada mata pencaharian lain. Bagi petani garam yang masih mempertahankan usahanya, kemampuan dalam melihat perubahan kondisi lingkungan harus senantiasa diperhatikan. Hal ini dikarenakan, lingkungan menjadi kunci keberhasilan dan kesuksesan petani garam dalam menjalankan usaha pembuatan garam di Desa Kuwu.

Untuk dapat bertahan dan menjaga kelangsungan hidup, setiap individu harus peka terhadap perubahan yang ada di lingkungan. Hal ini dikarenakan kelangsungan untuk beradaptasi mempunyai nilai bagi kelangsungan setiap makhluk hidup di dunia. Makin besar kemampuan beradaptasi, maka makin besar pula kelangsungan hidup suatu jenis (Soemarwoto 2004:45).

Menurut Moran (dalam Iskandar, 2006 : 186) telah dikenal tiga jenis penyesuaian manusia untuk mengadaptasikan dirinya dalam berbagai perubahan lingkungannya, yaitu penyesuaian fisiologi, perilaku, budaya. Penyesuaian fisiologi dan perilaku merupakan proses adaptasi secara biologi atau evolusi dari manusia untuk dapat survive dan bereproduksi, dan kemampuan ini bersifat pewarisan yang diturunkan secara genetik.namun demikian ada hal yang membedakan manusia dengan hewan. Manusia mempunyai kemampuan melakukan adaptasi dengan lingkungannya secara budaya. Ini adalah kemampuan yang tidak diwariskan secara genetic, tetapi diperoleh dengan cara belajar, berkat kemampuan untuk membuat, memahami, dan mengkomunikasikan ide-ide yang abstrak serta melakukan kelakuan simbolik, terutama karena manusia punya bahasa.. Adaptasi secara kebudayaan atau adaptasi tipe ketiga, difahami sebagai; "proses budaya yang terjadi dalam rangka untuk memelihara keseimbangan antara populasi penduduk dengan sumber daya alam dalam suatu ekosistem.

Sementara itu, Marzali (2003) menjelaskan secara luas bahwa strategi adaptasi adalah merupakan perilaku manusia dalam mengalokasikan sumberdaya yang 
mereka miliki dalam menghadapi masalahmasalah sebagai pilihan-pilihan tindakan yang tepat guna sesuai dengan lingkungan sosial, kultural, ekonomi, dan ekologis di tempat dimana mereka hidup.

Keberadaan petani garam pada kawasan Bledug Kuwu sampai sekarang masih dapat terlihat. Hal ini dapat diketahui dari masih terdapatnya 6 petani garam yang ada di Desa Kuwu, dimana diantara para petani garam yang lain sudah beralih profesi dan meninggalkan peralatan pembuat garam di tempat mereka dulu pernah bekerja. Kondisi tersebut memberikan gambaran bahwa strategi adaptasi yang dilakukan oleh petani garam di Desa Kuwu Kecamatan Kradenan Kabupaten Grobogan, merupakan sebuah upaya petani garam untuk menjaga kelangsungan usahanya di Desa Kuwu.

Permasalahan dalam penelitian ini adalah bagaimana strategi adaptasi budaya petani garam pada masyarakat Desa Kuwu Kecamatan Kradenan Kabupaten Grobogan. Dari permasalahan tersebut dirinci dalam pertanyaan penelitian sebagai berikut: bagaimana masalah lingkungan yang dihadapi, teknologi apa yang digunakan dan bagaimana perilaku petani garam di Desa Kuwu dengan adanya problem lingkungan dan teknologi yang digunakan.

\section{METODE PENELITIAN}

Penelitian ini dilaksanakan dengan metode kualitatif. Subyek penelitian dalam penelitian ini adalah petani garam yang masih bekerja dan masyarakat yang pernah bekerja sebagai petani garam di Desa Kuwu. Terdiri dari ibu Lasiem sebagai petani garam, bapak Ladiman sebagai petani garam, Bapak Salikin sebagai petani garam, Ibu Parsi sebagai petani garam, Bapak Parmo sebagai petani garam, Ibu Rami sebagai petani garam, Ibu Sriyatun sebagai petani sawah, Bapak Harjo sebagai penjual garam, dan Bapak Sugiyo sebagai petani sawah. Untuk informan pendukung dalam penelitian ini adalah aparat pemerintah Desa Kuwu yaitu bapak Trihandoko sebagai kepala Desa Kuwu, dan Ibu Suwarsiti sebagai Kasi sarana prasarana dan pendapatan wisata dari Dinas Pemuda Olah Raga Kabudayaan dan Pariwisata Kabupaten Grobogan. Metode pengumpulan data dalam penelitian ini adalah observasi, wawancara, dan dokumentasi.

\section{HASIL DAN PEMBAHASAN}

Adaptasi lingkungan yang dilakukan oleh petani garam di Desa Kuwu, disebabkan oleh adanya permasalahan lingkungan yang menuntut petani garam untuk menyesuaikan diri dengan lingkungan melalui perilakuperilaku. Perilaku yang dilakukan petani garam di Desa Kuwu dalam menghadapi permasalahan lingkungan, merupakan wujud dari adaptasi yang mendukung ketahanan hidup dalam menghadapi kondisi lingkungan yang selalu berubah. Dalam hal ini, MacCarl \& Hurd (2001), Yohe \&Tol (2002), Stern.et.al (2006) (dalam Nurasa \& Iqbal, 2009 : 68) menyatakan bahwa pertanian merupakan salah satu sektor perekonomian yang rawan terhadap pengaruh negatif perubahan iklim. Untuk mempertahankan kelangsungan hidupnya maka petani harus memiliki strategi adaptasi yang tepat sesuai dengan permasalahan yang sedang dihadapi.

Problem lingkungan yang dihadapi oleh petani garam di Desa Kuwu dalam memanfaatkan air garam mencakup tiga hal. Pertama adalah perubahan cuaca yang tidak menentu. Perubahan cuaca yang tidak menentu di wilayah Indonesia tentunya mempunyai dampak terhadap kelancaran proses produksi garam yang dilakukan oleh petani garam di Desa Kuwu. Hal ini dikarenakan segala aktifitas kegiatan yang dilakukan oleh petani garam sangat tergantung pada cuaca yang ada di lingkungan. Perbedaan antara petani garam yang mampu beradaptasi dan tidak mampu beradaptasi di lingkungan Desa Kuwu, dapat dilihat dari keberadaan gubug yang dimiliki petani garam di sekitar letupan lumpur Bledug Kuwu. Petani garam yang mampu beradaptasi mempunyai gubug yang masih difungsikan dengan baik. Kondisi berbeda dapat terlihat pada petani garam yang tidak mampu beradaptasi, 
gubug yang dimiliki petani garam sudah terlihat roboh dan tidak difungsikan lagi. Selain tidak terurusnya gubug yang dimiliki petani garam, kondisi ini juga mengganggu keindahan lokasi Bledug Kuwu karena letak dari pembuatan garam berada di dalam kawasan Bledug Kuwu. Munculnya sifat-sifat yang tidak sesuai dengan lingkungan tersebut disebabkan oleh gagalnya individu dalam beradaptasi. Hal tersebut sesuai dengan pernyataan Soemarwoto (2004:48) bahwa "adaptasi yang tidak berhasil menghasilkan sifat yang tidak sesuai dengan lingkungan, dan sifat tersebut disebut maladaptasi". Mal adaptasi mengurangi kementakan untuk kelangsungan hidup. Dengan demikian maladaptasi bisa terjadi pada petani garam yang gagal beradaptasi dengan lingkungan di Desa Kuwu, dimana hal ini dapat mengurangi kelangsungan hidup petani garam lain di lingkungan masyarakat Desa Kuwu.

Kedua, kondisi lumpur Bledug Kuwu. Kondisi lumpur yang ada di Bledug Kuwu setiap waktu selalu berubah, hal ini dipengaruhi oleh kondisi curah hujan yang ada di Desa Kuwu. Semakin tinggi curah hujan yang ada di Desa Kuwu maka semakin tinggi pula kelembekan lumpur yang ada di Bledug Kuwu. Hal ini biasanya terjadi pada musim penghujan yaitu pada bulan Oktober sampai Maret. Adanya perbedaan kelembekan lumpur di Bledug Kuwu, turut mempengaruhi keberadaan petani garam dalam mempertahankan usahanya. Hal ini dikarenakan dalam proses pengambilan air garam, petani garam harus berjalan menyusuri lumpur Bledug Kuwu untuk membuat parit dan mengalirkan air garam menuju sumur penampungan. Pemanfaatan sumber air garam oleh para petani garam berasal dari letupan lumpur Bledug Kuwu yang kecil. Pemilihan bledug kecil sebagai sumber pengambilan air garam, dikarenakan petani garam lebih mudah dalam mengambil dan dalam proses pengambilannya tidak membahayakan karena letupan lumpur yang keluar relatif kecil.

Ketiga, karakteristik air garam. Selain berpengaruh terhadap kondisi lumpur yang ada di Bledug Kuwu, faktor cuaca juga berpengaruh terhadap kandungan air garam. Semakin tinggi curah hujan yang ada di Desa Kuwu, maka semakin rendah kandungan garam yang ada pada air garam. Hal ini dikarenakan air garam yang ada di dalam lumpur Bledug Kuwu tercampur dengan air hujan. Dengan semakin rendahnya kandungan garam yang ada pada sumber letupan lumpur, akan berdampak pada lamanya proses produksi garam yang dihasilkan para petani garam di Desa Kuwu. Oleh karena itu untuk menghindari bercampurnya air garam dengan air hujan, petani garam melakukan penampungan air garam pada musim kemarau.

Adanya aktifitas pembuatan garam yang dilakukan oleh petani garam di Desa Kuwu, secara tidak langsung akan terjalin hubungan antara petani garam dan lingkungan sekitar. Hal tersebut sesuai dengan pernyataan yang dikemukakan oleh Woodworth dan Marquis (dalam Soeparwoto 2005:149-150) bahwa "individu menggunakan lingkungan dan individu menyesuaikan diri dengan lingkungan". Terkait dengan penggunaan lingkungan, petani garam memanfaatkan air garam yang keluar bersama letupan lumpur Bledug Kuwu, sedangkan dalam penyesuaian diri dengan lingkungan petani garam berusaha beradaptasi dengan kondisi lingkungan dalam menghadapi permasalahan lingkungan dan teknologi.

Selain itu adaptasi yang dilakukan oleh petani garam juga sesuai dengan yang dikemukakan oleh Kaplan dan Robert A. Manners (2002:112) bahwa "adaptasi adalah proses yang menghubungkan sistem budaya dengan lingkungan". Dengan demikian adaptasi yang dilakukan petani garam merupakan proses yang menghubungkan sistem budaya yaitu teknologi pembuat garam dengan kondisi lingkungan Desa Kuwu.

Dengan adanya problem lingkungan yang dihadapi oleh petani garam di Desa Kuwu yaitu perubahan cuaca, kelembekan lumpur Bledug Kuwu, dan karakteristik air garam, petani garam memerlukan adanya teknologi untuk mempertahankan eksistensi dalam menghadapi permasalahan yang ada 
di lingkungan. Teknologi yang digunakan oleh petani garam adalah peralatan tradisional yang digunakan untuk membuat garam. Teknologi yang digunakan oleh petani garam di Desa Kuwu adalah sebagai berikut : siwur. Siwur digunakan untuk mempermudah pengambilan air garam dalam sumur penampungan. Siwur terbuat dari batok kelapa yang dibelah menjadi 2 dan diberi lubang untuk pegangan tangan dari bambu apus. Pemilihan bahan dari batok kelapa dan bambu apus sebagai pegangan, dikarenakan bahan tersebut tidak cepat rusak apabila terkena air garam. Dalam proses pembuatan garam sebelum air garam masuk dalam sumur penampungan, petani garam membuat parit-parit di sekeliling keluarnya lutupan lumpur Bledug Kuwu kecil untuk menampung air garam. Jarak antara parit dengan sumber letupan Bledug Kuwu kecil adalah \pm 10 meter, hal ini dilakukan karena jarak tersebut menjadi jarak yang aman bagi petani garam untuk mengalirkan air garam. Parit yang dibuat mengelilingi letupan lumpur kemudian dikumpulkan menjadi satu untuk menuju ke sumur penampungan air garam. Dalam proses penampungan air garam, air garam tidak boleh tercampur dengan air hujan karena hal tersebut dapat mengakibatkan lamanya proses pembentukan garam pada klakah. Sumur penampungan yang dimiliki oleh petani garam biasanya mempunyai kedalaman \pm 2 meter.

Klakah digunakan oleh petani garam untuk menjemur air garam di bawah terik sinar matahari. Klakah terbuat dari bambu peting yang dibelah menjadi dua. Untuk ukuran panjang klakah yang dibuat petani garam antara satu dan lainnya mempunyai ukuran yang berbeda, hal ini bertujuan untuk mempermudah penumpukan apabila turun hujan dan agar terlihat lebih rapi. Belahan bambu yang telah terpotong, kemudian di susun dan diikat membentuk sap dengan menggunakan bilahan bambu apus. Untuk setiap sap klakah terdiri dari 6 atau 7 belah bambu. Dalam hal ini jumlah sap bambu yang dimiliki oleh petani garam dapat mencapai 21 buah. Pemilihan media bambu sebagai tempat menjemur air garam, karena hasil yang didapat lebih bersih dan tidak tercampur dengan tanah. Dalam kegiatan penjemuran air garam, petani garam menggunakan alat bantu siwur untuk menuangkan air garam ke dalam klakah, dan penuangan air garam dilakukan $\pm 3 / 4$ dari kedalaman klakah. Hal ini dilakukan agar dalam pengangkatan dan penjantuan tidak tumpah keluar. Dalam penggunaan peralatan pembuat garam, salah satu kendala yang sering dialami oleh petani garam terjadi pada klakah. Kendala tersebut adalah seringnya terjadi kerusakan pada klakah. Hal ini dikarenakan klakah merupakan peralatan sederhana dan telah digunakan secara turun temurun. Berbagai upaya telah dilakukan oleh petani garam untuk mengatasi kendala tersebut. Salah satunya adalah mengganti klakah dengan seng atau pipa paralon namun hasil yang didapat tidak sesuai dengan yang diharapkan.

Kepyur berfungsi sebagai alat untuk mempercepat pembentukan butiran garam di dalam klakah pada waktu dijemur. Kepyur terbuat dari merang padi diikat menggunakan bilahan bambu apus dan diberi pegangan tangan di bawahnya. Cara penggunaan kepyur adalah dengan menaburnaburkan bersama dengan air bleng di atas klakah pada saat butiran garam sudah mulai terbentuk. Proses penaburan air bleng di atas klakah dengan menggunakan alat bantu kepyur disebut penjantuan. Tujuan dilakukan penjantuan adalah untuk mempercepat pembentukan butiran garam pada klakah. Waktu yang paling tepat untuk dilakukan penjantuan adalah pada waktu butiran garam sudah mulai terbentuk. Lama proses penjantunan dipengaruhi oleh kondisi cuaca yang ada di lingkungan, semakin panas cuaca yang ada di Desa Kuwu maka semakin cepat proses pembentukan butiran garam pada klakah. Pada musim kemarau proses penjantuan dapat dilakukan pada hari ke 5 setelah penuangan air garam ke dalam klakah, namun pada musim penghujan lama waktu tidak bisa ditentukan.

Kerik digunakan oleh petani garam di Desa Kuwu untuk mengambil butiran garam yang sudah jadi dan siap untuk dipanen dari klakah. Kerik yang terbuat dari seng 
dibentuk seperti perahu dengan ujungnya dibuat agak meruncing. Pada kedua ujung sebuah kerik dibuat tidak sama, salah satu ujung kerik dibuat meruncing dan salah satu ujungnya dibuat agak tumpul. Tujuannya adalah mempermudah pengambilan butiran garam pada klakah yang sulit dijangkau. Pemilihan bahan seng oleh petani garam dikarenakan bahan dari seng bentuknya mudah disesuaikan dengan klakah dan tidak cepat rusak apabila terkena butiran garam.

Blonjong digunakan oleh petani garam di Desa Kuwu untuk mentiriskan garam agar terpisah antara air garam yang masih tercampur dengan butiran garam. Blonjong terbuat dari anyaman bambu yang pada sisi kanan, kiri, dan bawahnya terdapat lubang kecil yang berfungsi sebagai tempat keluarnya air garam yang masih tercampur dengan butiran garam saat selesai dipanen. Air hasil tirisan dari blonjong disebut air bleng, yang dapat digunakan untuk mempercepat pembentukan garam dengan bantuan kepyur serta dapat digunakan untuk membuat kerupuk puli.

Ngaron, digunakan oleh petani garam di Desa Kuwu untuk menampung air bleng dari blonjong saat selesai dipanen. Ngaron terbuat dari tanah liat mempunyai ukuran diameter $\pm 15 \mathrm{~cm}$, sangat sesuai untuk tempat menampung air bleng dari blonjong. Ember digunakan oleh petani garam di Desa Kuwu untuk tempat menampung garam saat selesai memanen dan selesai ditiriskan dari blonjong. Ember yang digunakan petani garam berukuran kecil dengan diameter $\pm 25 \mathrm{~cm}$. Pemilihan ember sebagai tempat menampung garam, dikarenakan ember terbuat dari bahan karet sehingga tidak cepat rusak apabila digunakan untuk menampung garam.

Payon digunakan untuk menutup klakah agar terlindung dari air hujan, sehingga air garam yang ada di dalam klakah tidak tercampur dengan air hujan. Payon terbuat dari rumput alang-alang yang di susun rapat dan diikat menggunakan bilahan bambu apus. Ukuran payon yang dibuat petani garam disesuaikan dengan ukuran panjang klakah yang digunakan untuk membuat garam, yaitu dapat mencapai 3 meter. Kendala yang dihadapi petani garam dari penggunaan payon adalah semakin sulit memperoleh bahan untuk membuat payon. Biasanya petani garam memperoleh bahan dengan membeli pada petani di sawah, namun kesulitan memperoleh rumput alangalang sekarang semakin dirasakan oleh para petani garam di Desa Kuwu.

Dengan semakin sulitnya mendapatkan rumput alang-alang sebagai media membuat payon, petani garam berupaya mengganti rumput alang-alang dengan layar atau kepang. Upaya penggantian yang dilakukan oleh petani garam tersebut, ternyata tidak mampu bertahan lama seperti yang diharapkan oleh petani garam. Hal ini dikarenakan bahan layar atau kepang sebagai media payon tidak mampu bertahan lama apabila terkena air garam.

Adanya upaya yang dilakukan oleh petani garam di Desa Kuwu dalam menghadapi permasalahan teknologi merupakan salah satu bentuk adaptasi di lingkungan Desa Kuwu. Hal tersebut sesuai dengan pernyataan yang dikemukakan oleh Soemarwoto (2004:45-46) tentang adaptasi kultural (adaptasi perilaku), yaitu "adaptasi yang didasari oleh perilaku individu dalam menghindari bahaya yang ada pada lingkungan". Dalam hal ini adaptasi yang dilakukan oleh petani garam di Desa Kuwu adalah salah satu bentuk adaptasi kultural, karena perilaku yang dilakukan untuk menghadapi perubahan lingkungan dan mencukupi kebutuhan.

Dalam adaptasi kultural, upaya yang dilakukan oleh petani garam tidak hanya untuk menghindari bahaya yang ada di lingkungan, namun juga terjadi pada penggunaan teknologi peralatan yang dimiliki petani garam. Hal tersebut sesuai dengan pernyataan Soemarwoto (2004:47) bahwa "selain didasari pada perilaku individu dalam menghindari bahaya yang ada di lingkungan, adaptasi kultural juga terjadi pada penggunaan teknologi". Teknologi yang digunakan oleh petani garam adalah peralatan pembuat garam yang bersifat tetap, sehingga dapat menjadi ciri khas yang membedakan dengan petani garam dari daerah lainnya. 
Hal ini sesuai dengan pernyataan Julian Steward. Bahwa untuk menjelaskan adanya variasi di daerah tertentu, Julian Steward (dalam Haviland 1985:12) menyatakan konsep tipe kebudayaan (culture type) adalah "kebudayaan yang ditinjau berdasarkan teknologi tertentu dan hubungannya dengan sifat-sifat lingkungan yang ditangani dengan menggunakan teknologi tersebut". Dalam hal ini teknologi peralatan yang digunakan oleh petani garam di Desa Kuwu dapat menjadi salah satu variasi kebudayaan yang terdapat di suatu daerah.

Dengan adanya permasalahan lingkungan dan teknologi yang dihadapi petani garam di Desa Kuwu, diperlukan adanya strategi yang tepat untuk menjaga kelangsungan usaha di lingkungan masyarakat. Strategi yang dimiliki oleh petani garam diwujudkan melalui perilakuperilaku dalam menjalankan usaha pembuatan garam. Usaha yang dilakukan oleh petani garam yang pertama adalah melakukan penimbunan. Penimbunan dilakukan untuk menjaga kebutuhan garam Kuwu di pasaran, selain itu alasan lain dari petani garam adalah hasil panen yang didapat pada musim kemarau cenderung berlebihan. Hal ini dilakukan karena hasil panen yang didapat petani garam pada musim kemarau rata-rata 50 kilogram dalam sekali panen setiap minggunya. Hasil tersebut tidak semuanya dijual ke pasaran, namun dilakukan penimbunan untuk dijual kembali pada musim penghujan.

Penimbunan tidak hanya dilakukan terhadap garam saja, namun juga pada air bleng dan air garam. Upaya yang dilakukan petani garam dan para pedagang garam agar hasil timbunan dapat bertahan lama adalah dengan meletakkan di tempat yang kering dan cukup sinar matahari. Selain untuk mencukupi kebutuhan barang dagangan, usaha penimbunan garam yang dilakukan oleh petani garam dan para pedagang adalah untuk mendapatkan keuntungan dari hasil penjualan garam pada musim penghujan. $\mathrm{Hal}$ ini dikarenakan pada musim penghujan petani garam dapat menaikkan harga garam yang dijual di pasaran. Dimana harga semula dari garam adalah $\mathrm{Rp}$ 1.500,00 per kilogram pada musim kemarau, naik menjadi $\mathrm{Rp} 3.000,00$ per kilogram pada musim penghujan.

Dengan kenaikan sebesar dua kali lipat dari harga semula, maka pendapatan yang diperoleh petani garam juga mengalami kenaikan. Sebelum menaikkan harga garam, antara petani garam dan pedagang garam terlebih dahulu terjadi kesepakatan tentang kapan dan berapa besar kenaikan harga garam yang akan dijual. Hal ini dilakukan agar terjadi kesamaan dalam menentukan harga jual garam kepada konsumen.

Kedua, membuat peralatan sendiri. Untuk menjaga peralatan agar senantiasa baik dan dapat difungsikan sebagaimana mestinya, petani garam selalu memperbaiki peralatan pembuat garam setiap kali terdapat kerusakan. Upaya yang dilakukan oleh petani garam dengan membuat peralatan sendiri merupakan salah satu strategi adaptasi dalam menghadapi kendala peralatan. Salah satu contoh pembuatan peralatan yang dilakukan petani garam adalah kepyur. Pembuatan kepyur biasa dilakukan sendiri oleh petani garam di Desa Kuwu dari bahan merang padi yang diperoleh dari petani di sawah. Merang padi sebelum dibentuk menjadi kepyur dibersihkan dahulu dari padi yang masih menempel, kemudian diukur dengan panjang $\pm 25 \mathrm{~cm}$. Teknologi pengolahan ini penting untuk dikembangkan berkaitan dengan eksistensi petani garam tersebut. Menurut Suhartini (2009) perkembangan yang terwujud karena adanya inovasi (discovery maupun invention) dan difusi inovasi mempercepat proses teknologi, industrialisasi dan urbanisasi. Ketiga komponen tersebut secara bersama menghasilkan proses modernisasi dalam suatu masyarakat yang bersangkutan. Teknologi modern secara disadari atau tidak oleh masyarakat, sebenarnya menciptakan keinginan dan harapan-harapan baru dan memberikan cara yang memungkinkan adanya peningkatan kesejahteraan manusia.

Ketiga, mencari pekerjaan sambilan. Untuk meningkatkan pendapatan yang diperoleh petani garam, usaha yang dilakukan adalah dengan mencari pekerjaan sambilan. Pemilihan usaha sambilan ini 
dilakukan karena pendapatan yang diperoleh dari pembuatan garam tidak menentu, sehingga petani garam berusaha mencari pekerjaan sambilan untuk meningkatkan pendapatan dan untuk mencukupi kebutuhan. Penentuan mencari pekerjaan sambilan ini menjadi alternatif yang sangat logis mengingat kebutuhan hidup yang harus dipenuhi. Hal ini sesuai dengan pendapat Sumarti (2007) bahwa kemiskinan yang melanda petani karena keterbatasan usaha yang dilakukannya dapat dipenuhi minimal dengan strategi nafkah ganda pada petani di pedesaan. Strategi nafkah ganda yang dilakukan untuk mengatasi kemiskinan ini sangat tepat, karena disesuaikan dengan situasi kultural, sosial, ekonomi, politik, dan ekologi tempat tersebut. Strategi yang diterapkan tersebut didasarkan pada kepentingan ekonomi maupun sosial, yaitu pada tindakan untuk penciptaan peluang usaha dan kerja serta penanggulangan resiko usaha.

Pemilihan pekerjaan sambilan antara petani garam satu dan lain berbeda, hal ini disebabkan perbedaan kemampuan yang dimiliki petani garam dalam memanfaatkan peluang usaha maupun kemampuan dalam kepemilikan modal. Ragam pekerjaan sambilan yang dimiliki oleh petani garam adalah bertani di sawah dan memelihara ikan nila di kolam. Dengan adanya penyesuaian perilaku dari petani garam, maka hal tersebut merupakan bentuk adaptasi dengan lingkungan. Dimana keberhasilan dalam beradaptasi dengan lingkungan dapat dibuktikan dari eksistensi petani garam di Desa Kuwu.

Hal ini sesuai dengan pernyataan dari Bannett (dalam Putra dkk 2003:11) bahwa "adaptif atau tidaknya suatu perilaku dapat ditentukan atas dasar tercapai tidaknya tujuan yang diinginkan (goal statis-faction)". Dalam hal ini adaptif atau tidaknya perilaku yang dilakukan oleh petani garam dapat dilihat dari keberadaan petani garam di lingkungan masyarakat Desa Kuwu. Perilaku-perilaku yang dilakukan oleh petani garam di Desa Kuwu merupakan wujud mempertahankan eksistensinya di lingkungan masyarakat.

Di lain pihak, kondisi petani dan pertanian ini harus pula mendapat dukungan pemerintah. Peran pemerintah juga menjadi sangat penting, dimana petani garam dalam hal ini membutuhkan lebih dari sekedar uluran tangan dan wacana penyelamatan, namun harus bersifat lebih kongkrit. Menurut Supadi (2006) pemberdayaan petani perlu didukung oleh: 1) bantuan dana sebagai modal usaha, 2) pembangunan prasarana sebagai pendukung pengembangan kegiatan sosial ekonomi rakyat, 3) penyediaan sarana pemasaran, 4) pelatihan bagi petani dan pelaksana, dan 5) penguatan kelembagaan sosial ekonomi masyarakat. Senada dengan hal tersebut, Elizabeth (2007) mengemukakan bahwa diperlukan revitalisasi melalui peningkatan peran (pemberdayaan) petani sebagai asset pembangunan. Hal ini perlu diarahkan pada proses efisiensi usahatani guna meningkatkan produktivitas dan pendapatan petani, pemerataan akses dan kontrol terhadap sumberdaya ekonomi (lahan dan modal) dan jaringan pasar, serta bertumpu pada keseimbangan ekologi sehingga

dapat berkelanjutan. Dengan hal tersebut, diharapkan ada benang merah yang dapat menghubungkan antara kebijakan negara di tingkat pusat dengan perilaku adaptasi petani yang harus bergelut dengan situsi keseharian.

\section{SIMPULAN}

Permasalahan lingkungan yang dihadapi oleh petani garam mencakup perubahan cuaca yang tidak menentu, kondisi lumpur yang selalu berubah, dan karakteristik air garam. Dengan adanya permasalahan lingkungan tersebut, tidak semua petani garam mampu untuk beradaptasi dengan lingkungan, karena kemampuan setiap orang dalam beradaptasi berbeda-beda.

Untuk menghadapi problem lingkungan yang ada di Desa Kuwu, petani garam melakukan adaptasi kultural. Dalam adaptasi kultural, petani garam tidak hanya menghindari bahaya yang ada di lingkungan, namun juga penggunaan teknologi yang dimiliki oleh petani garam 
di Desa Kuwu. Teknologi yang digunakan meliputi klakah, blonjong, siwur, kepyur, payon, ember, dan kerik. Dengan adanya problem lingkungan dan teknologi yang digunakan oleh petani garam, usaha yang dilakukan untuk menghadapi permasalahan tersebut diwujudkan melalui perilaku-perilaku dalam menjalankan aktifitas pembuatan garam. Perilaku-perilaku tersebut adalah melakukan penimbunan garam, membuat peralatan pembuat garam sendiri, dan mencari pekerjaan sambilan. Selain itu perhatian dan bantuan dari pemerintah sangat diharapkan mengingat teknologi yang digunakan oleh para pembuat garam ini masih sangat tradisional dan hanya dapat memproduksi garam dalam jumlah yang sedikit.

\section{DAFTAR PUSTAKA}

Elizabeth, R. 2007. Fenomena Sosiologis Metamorphosis Petani: Ke Arah Keberpihakan Pada Masyarakat Petani Di Pedesaan Yang Terpinggirkan Terkait Konsep Ekonomi Kerakyatan. Forum Penelitian Agro Ekonomi. 25 (1): 29-42.

Haviland, W. A. 1985. Antropologi. Jakarta: Erlangga. Iskandar, J. 2006. Metodologi Memahami Petani dan Pertanian. Jurnal Analisis Sosial. 11 (1): 25-45.
Kaplan, D. \& Manners, R.A. 2002. Teori Budaya. Yogyakarta: Pustaka Pelajar.

Marzali, A. 2003. Strategi Peisan Cikalong dalam Menghadapi Kemiskinan. Jakarta : Penerbit Yayasan Obor Indonesia.

Nasrullah dan Wahyu. 2012. Kearifan Lokal Petani Dayak Bakumpai dalam Pengelolaan Padi di Lahan Rawa Pasang Surut. Jurnal Komunitas. 4 (1): 31-40.

Nurasa, T. \& Iqbal, M. 2009. Adaptasi dan Antisipasi Petani Serta Strategi Penerapan Sistem Usaha Tani Dalam Mengatasi Fenomena Perubahan Iklim Di Propinsi Nusa Tenggara Timur. Jurnal Sosio Ekonomika, 15 (2): 75-85.

Putra, H.S.A. 2003. Ekonomi, Moral, Rasional dan Politik Dalam Industri Kecil di Jawa. Yogyakarta: Kepel Press.

Soemarwoto, O. 2004. Ekologi, Lingkungan Hidup dan Pembangunan. Jakarta: Djambatan.

Suhartini. 2009. Kajian Kearifan Lokal Masyarakat Dalam Pengelolaan Sumberdaya Alam Dan Lingkungan. Prosiding Seminar Nasional Penelitian, Pendidikan Dan Penerapan MIPA, Fakultas MIPA, Universitas Negeri Yogyakarta, 16 Mei 2009.

Sumarti, T. 2007. Kemiskinan Petani dan Strategi Nafkah Ganda Rumahtangga Pedesaan. Sodality : Jurnal Transdisiplin Sosiologi, Komunikasi, dan Ekologi Manusia. 1 (2): 100-115.

Supadi, \& Nurmanaf, A.R. 2006. Pemberdayaan Petani Kelapa Dalam Upaya Peningkatan Pendapatan. Jurnal Litbang Pertanian, 25 (1): $70-85$. 